\title{
The self ignition of fiberglass lines
}

\author{
Moussa Bounoughaz ${ }^{1,2, *}$, Noura Touabi ${ }^{1,2}$ \\ ${ }^{1}$ Département de Chimie, Faculté des Sciences, Université M'hamed Bougara, Boumerdès, Algeria \\ ${ }^{2}$ Laboratoire Traitement et Mise en Forme des Polymères Fibreux, Département Génie des Procédés, \\ Faculté Sciences de l'Ingénieurs, Boumerdes Université M'hamed Bougara, Boumerdès, Algeria \\ *E-mail address: moussa_bounoughaz@yahoo.fr
}

\begin{abstract}
The fiberglass pipes were used for transportation of water in order to maintain the pressure in the oil field of Zarzaitine (Region of In Amenas located in the south of Algeria). During the maintenance work in summer, a season well known for its extensive heat, the deposits contained in the pipe, and after its contact with the atmosphere, have caused a smoke and it was followed by a fire that ignited a portion of the pipe. To give an answer to the causes of this phenomenon, we have first incriminated the role of specific bacterial species and therefore we have made a microbiological analysis of the deposits collected from the site of the incident. The obtained results revealed the presence of a heterogeneous microbial population with a high concentration level of sulfate-reducing bacteria (SRB), methanogenic bacteria (MB), yeasts and fungi. The interaction between the different species of bacteria and the organic matter contained in the deposits has generated the formation of methane which under the influence of the great heat burnt and the fire caused the ignition of the fiberglass line.
\end{abstract}

Keywords: Self-ignition; deposits; fiberglass; aerobic bacteria; facultative anaerobic; sulfate-reducing bacteria; methanogenic bacteria

\section{INTRODUCTION}

Zarzaitine oil field located in the south of Algeria was known for the self ignition that it was produced in the fiberglass lines that were transformed into embers a few hours after its opening for maintenance. These lines were used to collect water from wells. These waters produced by gas lift process were treated by additives like biocides, corrosion inhibitors and oxygen scavengers. Biocides and corrosion inhibitors were injected in the bottom of wells. Incompatible additives form an organic scale that precipitate in the bottom of lines. With the presence of bacteria, the organic phase of scale may be altered and thus forms several products like methane $\left(\mathrm{CH}_{4}\right)$, sulfur acid $\left(\mathrm{H}_{2} \mathrm{~S}\right)$, carbon dioxide $\left(\mathrm{CO}_{2}\right)$ and oxygen $\left(\mathrm{O}_{2}\right)$. At the same time, operators in charge of maintenance of the unit of Closing Gas Lift (CGL) have noticed the increase in temperature of the deposits removed from capacities and separators of CGL unit. These deposits where transformed into embers. All these phenomena occurred during the month of July when the temperature is usually very high. Deposits, after their contact with the atmosphere, produced a smoke and turned into a brazier causing the auto inflammation of fiberglass pipes. 
According to researchers [1] sulfate reduction may cause several problems in the anaerobic treatment process and have been studied regarding the following points:

(a) sulfate is reduced to hydrogen sulfide which is a strong inhibitor of methanogenesis bacteria;

(b) sulfide has a piquant odor and exerts a high oxygen demand in the effluent;

(c) hydrogen sulfide released to the biogas causes corrosion downstream;

(d) sulfate reducing bacteria (SRB) competes with other bacteria associated with methane production. The methanogenesis as the terminal step of anaerobic degradation yields to a competition between SRB and methane producing bacteria (MPB).

As reported by researchers [2], sulfate reduces to $\mathrm{H}_{2} \mathrm{~S}$ and oxidizes organic matter to produce $\mathrm{CO}_{2}$ and the alkalinization of medium in anaerobic process. The organic matter breaks down into $\mathrm{CH}_{4}$ and $\mathrm{CO}_{2}$ and it can be expressed as follow:

$$
\begin{aligned}
\text { Organics }+\mathrm{SO}_{4}{ }^{2-} & \rightarrow \text { Cells alkalinity }+\mathrm{H}_{2} \mathrm{~S}+\mathrm{CO}_{2} \\
\text { Organics } & \rightarrow \text { Cells }+\mathrm{CH}_{4}+\mathrm{CO}_{2} \\
\text { Organics }+\mathrm{SO}_{4}{ }^{2-} & \rightarrow \text { Cells }+\mathrm{H}_{2} \mathrm{~S}+\mathrm{CH}_{4}+\text { Alkalinity }
\end{aligned}
$$

The temperature of the auto ignition is the minimum temperature in which a material must be heated to initiate combustion without the need of external flame $[3,4]$. Fei et al propose the mechanism for self ignition and they suggest that the heat generated by exothermic reaction will not dissipate in time. The combustion occurs at the place where oxygen exists. The sequences of self ignition go as follows:

First, the material must exhibit self heating.

Second, self heating must reach a critical high temperature rapidly.

Third, a sustained smoldering starts.

Fourth, the sustained smoldering reaches the outside of the material then erupts into flaming.

The spontaneous ignition is an uncontrolled and undesirable action and may lead to serious damages in many areas of the economical and industrial sectors [5]. The same results were observed within the scales founded into the down areas of the capacities of CGL unit in In Amenas oilfields.

Spontaneous ignition was observed regularly in coal mines and storage facilities and piles of plastic, dust, and tires. Auto ignition temperature (AIT) was identified as the temperature at which no heat transfer occurred between the surface and the center of the sample and in some other studies AIT was the temperature at which the sample temperature equaled the temperature of the furnace. The crossing-point method was adopted in this study to determine the AIT for various components of solid waste, determined as the point of equal temperature between the surface and the center of the sample [6]. Moisture can generally promote chemical self-heating and the heat generated from chemical oxidation plays a major role in spontaneous combustion.

As reported by authors [7-8], fresh organic waste is sensitive to oxidation by biodegradation and presents a higher risk for spontaneous combustion. The biodegradation is accelerated by the intense activity of bacteria. The presence of carbon monoxide (CO) gas gives a good indication for imminent self ignition 
A biological reaction that causes the self-heating of organic agricultural products is usually the oxidation assisted by microorganisms in the presence of water. Other chemical compounds, mainly inorganic, react with water to produce heat and can cause spontaneous ignition. Materials that react with water are not combustible themselves, but they produce sufficient heat to ignite nearby combustibles or flammable gases produced by the reaction [9].

The injected water is characterized by the presence of high concentration in sulfates, Sulfate Reducing Bacteria (SRB), and sufficient biodegradable organic materials and nutriments. In the absence of oxygen, the metabolism and the growth of SRB produces hydrogen sulfide $\left(\mathrm{H}_{2} \mathrm{~S}\right)[10]$.

Methane $\left(\mathrm{CH}_{4}\right)$ is stable in anaerobic environments. It poses a distinct explosion hazard when it is in the range of 5.53-14 \% (v/v) in the presence of oxygen. Methane concentration in the explosive range is of particular concern in the confined space of underground mining environments where the hazards of accidental ignition of methane may be further compounded by coal dust explosions [11].

In the same order, Albert et al [12] mentioned that the accumulation of hydrogen sulfide in sewer systems is a well known problem resulting in sewer wall corrosion, serious health hazards and odor. Hydrogen sulfide $\left(\mathrm{H}_{2} \mathrm{~S}\right)$ is formed when the organic matter present in sewage is oxidized under sulfate-reducing anaerobic conditions. However, hydrogen sulfide is not the unique compound formed from the sewer systems.

\section{MATERIALS AND METHODS}

Four scale samples were collected from different levels of the filtration battery located in the head of the well used for injecting water. Sediments were identified as follow: dry sediment (DS), humid sediment (HS), sediment of surface (SS) and sediment from the depth of filters (SD). All the samples were introduced into sterile plastic bags.

Samples from injection water and water formation have been collected at the head of injecting well water and from head of oil well respectively. All The samples were filled with overflow in sterile glass bottles to prevent their contact with air and then sealed with rubber stoppers. Scales and water samples were transported by ice box and were analyzed within two days. Table 1 presents the chemical composition of the injection and formation water samples collected at Zarzaitine oil field.

Table 1. Chemical composition of the injection and formation waters.

\begin{tabular}{ccc}
\hline Elements (mg/l) & Injection water & Formation water \\
\hline $\mathrm{Na}^{+}$ & 6600 & 30250 \\
$\mathrm{~K}$ & 120 & 655 \\
$\mathrm{Ca}^{2+}$ & 1026.0 & 11735.4 \\
$\mathrm{Mg}^{2+}$ & 311.3 & 1303.6 \\
$\mathrm{Sr}^{2+}$ & 20 & 230 \\
$\mathrm{Ba}^{+}$ & 0 & 1600.2 \\
$\mathrm{Fe}^{2+}$ & 0 & 20.03 \\
$\mathrm{Cl}^{-}$ & 9474.1 & 74176 \\
$\mathrm{CO}_{3}{ }^{2-}$ & 0 & 0 \\
$\mathrm{HCO}_{3}{ }^{-}$ & 275.7 & 72 \\
\hline
\end{tabular}




\begin{tabular}{ccc}
\hline $\mathrm{SO}_{4}{ }^{2-}$ & 3646.1 & 0 \\
\hline $\mathrm{pH}$ & 7.30 & 6.06 \\
\hline Hydrocarbon & 1.23 & 30.20 \\
\hline $\begin{array}{c}\text { Suspended matters } \\
\text { (filtered at } 0.45 \mu \mathrm{m})\end{array}$ & 112 & 496 \\
\hline
\end{tabular}

\section{1. Culture of bacteria}

Water injection was filtered, sterilized and used in the preparation of the medium of culture for SRB and MG. The medium used for enrichment and growth of SRB in the anaerobic conditions is formed by (in g/l): $0.5 \mathrm{KH}_{2} \mathrm{PO}_{4}, 1.0 \mathrm{NH}_{4} \mathrm{SO}_{4}, 1.0 \mathrm{Na}_{2} \mathrm{SO}_{4}, 1.0 \mathrm{CaCl}_{2}$ $6 \mathrm{H}_{2} \mathrm{O}, 2.0 \mathrm{MgCl}_{2} 7 \mathrm{H}_{2} \mathrm{O}, 3.5$ sodium lactate, 0.5 yeast extract, 0.1 ascorbic acid, 0.1 thioglycolic acid, $0.5 \mathrm{FeSO}_{4} 7 \mathrm{H}_{2} \mathrm{O}$ and 1.5 agar.

The $\mathrm{pH}$ of the media was adjusted to 7.6 with $\mathrm{NaOH}$ [13]. The dissolution was carried out by adding sterile water injection to maintain the same physiological concentration that yields to optimal conditions for bacterial growth. The chemical composition of this water is given in table 1. In each bottle, an iron nail of $6 \mathrm{~mm}$ was added to the medium. Medium culture was dispensed into penicillin bottles and made anaerobic by bubbling $\mathrm{N}_{2}-\mathrm{CO}_{2}$ in the range of 80:20 $\mathrm{v} / \mathrm{v}$ respectively.

The filled bottles were sealed with rubber stoppers and aluminum caps and then purged with mixed gas $\left(\mathrm{N}_{2}: \mathrm{CO}\right)$. The series of bottles were autoclaved and kept for later use. The medium of culture for yeast fungi was made from yeast $(10 \mathrm{~g} / \mathrm{l})$, malt extract $(7 \mathrm{~g} / \mathrm{l})$ and dextrose agar $(20 \mathrm{~g} / 1)$ [14].

The inoculums were prepared by dissolving $2 \mathrm{~g}$ of each samples in $250 \mathrm{ml}$ sterile flasks and filled with mediums as prepared previously. The flasks were introduced in adjustable incubators as shown in Table 2. The inoculums were serving as sources of high contamination by different germs to be used for counting, analysis and examinations.

Table 2. Inoculums incubator conditions.

\begin{tabular}{ccc}
\hline $\begin{array}{c}\text { Conditions } \\
\text { Boîtes pour bactéries }\end{array}$ & $\begin{array}{c}\text { Temperature } \\
\text { Of incubation }\end{array}$ & $\begin{array}{c}\text { Aerobic /Anaerobic } \\
\text { conditions }\end{array}$ \\
\hline Total germs & $37^{\circ} \mathrm{C}$ & Aerobic \\
Yeast fongi & $37^{\circ} \mathrm{C}$ & Aerobic \\
SRB & $37^{\circ} \mathrm{C}$ & Anaerobic \\
Methanogenic & $32^{\circ} \mathrm{C}$ & Anaerobic \\
Methanogenic & $37^{\circ} \mathrm{C}$ & Anaerobic \\
\hline
\end{tabular}

Methanogenic enrichment culture used for detecting and characterizing a methanogenic bacteria present in solutions was prepared from previous sediment samples. Liquid samples were transferred to a nutrient medium containing standard methanogenic substrates. The 
culture solutions filled into sterile vials were also sealed with rubber stoppers and aluminum caps, purged with mixed gas $\left(\mathrm{N}_{2}: \mathrm{CO}_{2}=8: 2\right)$ and incubated at $32{ }^{\circ} \mathrm{C}$ for 48 hours. Culture growth and production of methane serves as a positive indication of the presence of methanogenic bacteria. The culture medium used for the SRB growth was adapted for the methanogenic bacteria by adding supplemental trace elements, protein and enzymes [15], Agar was added to promote colonies growth on Petri boxes.

For enumerating SRB, $1 \mathrm{ml}$ of SRB inoculums was injected into penicillin bottle containing $9 \mathrm{ml}$ of specific medium for SRB. The bottle was shaken thoroughly, and the new sterile syringe was used to draw out $1 \mathrm{ml}$ sample and injected into a new medium bottle. This procedure was repeated to produce a serial of 6-8 bottles. The concentrations of inoculums in the bottles were $1 * 10^{0}, 110^{-1}, 1 * 10^{-2}$ and $1 * 10^{-n}$, where $\mathrm{n}$ is the last bottle in the serial. The anaerobic bottles were then incubated at $37^{\circ} \mathrm{C}$ and monitored daily for blackening due to $\mathrm{FeS}$ formation for up to 28 days [16].

\section{RESULTS AND DISCISION}

\section{1. Sulfate reducing bacteria (SRB)}

For SRB, enrichment cultures were incubated at $37{ }^{\circ} \mathrm{C}$ during 28 days. Growth was regarded as positive based on visual observation of the blackening of the medium of culture. The growth of SRB forms sulfur acid $\left(\mathrm{H}_{2} \mathrm{~S}\right)$ that reacts with iron nail to form black scale of iron sulfide (FeS). The microbiological characteristics of SRB were shown in table 3. All samples are highly contaminated by SRB $\left(>10^{5}\right.$ germs $\left./ \mathrm{ml}\right)$. The diameter of cells is less than $1 \mathrm{~mm}$, with the exception of the SD sample where the diameter of SRB bacteria was equal 1 $\mathrm{mm}$.

Cells were mobile and the microscopic examination revealed a Gram-negative for HS and SS samples and Gram positive for DS et SD samples. Three principal shapes of bacteria were observed: spherical (coccus), rod (bacillus) and twisted rod (spirillum). The coccus may be arranged in chains of cocci as in streptococcus, or in tetrads of cocci as in Sarcina. The diameter of SRB is less or equal than $1 \mathrm{~mm}$, which facilitates their accumulation in the battery of filtration since this latter has a smaller diameter that is equal to 0.45 microns.

The results shown in Table 3 revealed the presence of complex bacterial and archaeal communities that were involved in the reduction of sulfur-containing compounds (sulfate, thiosulfate, elemental sulfur) to sulfide. Thiosulfate, sulfur and sulfate-reducing bacteria have been commonly isolated from oil field and water production-injection systems.

A few decades ago, more attention was given to SRB regarding their influence on corrosion of metallic installations that causes economical losses for companies. SRB corrosion is one of the main factors causing the degradation of pipeline in oilfields. SRB tends to form a biofilm near the cathodic area.

The colonies located on the surface walls of separators and pipelines increase the rate of corrosion and lead to the pollution of soils and atmosphere by leaking considerable amounts of hydrocarbon (oil and condensate). Sulfate-reducing bacteria (SRB) contribute to souring as well as the production of sulfide in oil and gas fields.

$\mathrm{H}_{2} \mathrm{~S}$ gas is corrosive and toxic and as shown previously causes reservoir plugging. SRB reduces sulfate ions to sulfide ions $\left(\mathrm{S}^{2-}\right)$ that react with anodic iron ions and form iron sulfide $(\mathrm{FeS})$ that is deposited as corrosion products. The principle reactions explaining bacterial corrosion as reported by authors [17-18] are given by the following equations: 
Anode: $\quad 4 \mathrm{Fe} \rightarrow 4 \mathrm{Fe}^{2+}+8 \mathrm{e}^{-}$

Cathode: $8 \mathrm{H}^{+}+8 \mathrm{e}^{-} \rightarrow 8 \mathrm{H}$

Ionization of water:

$8 \mathrm{H}_{2} \mathrm{O} \rightarrow 8 \mathrm{H}^{+}+8 \mathrm{OH}^{-}$

Cathodic depolarization:

$\mathrm{SO}_{4}{ }^{2-}+8 \mathrm{H} \rightarrow \mathrm{S}^{2-}+4 \mathrm{H}_{2} \mathrm{O}$ (this reaction is promoted by the hydrogenase enzyme)

Corrosion products:

$\mathrm{Fe}^{2+}+\mathrm{S}^{2-} \rightarrow \mathrm{FeS}$

$3 \mathrm{Fe}^{2+}+6 \mathrm{OH}^{-} \rightarrow 3 \mathrm{Fe}(\mathrm{OH})_{2}$

The overall reaction of corrosion:

$4 \mathrm{Fe}+\mathrm{SO}_{4}{ }^{2-}+4 \mathrm{H}_{2} \mathrm{O} \rightarrow \mathrm{FeS}+3 \mathrm{Fe}(\mathrm{OH})_{2}+2 \mathrm{OH}^{-}$

Corrosion of carbon steel is accelerated by the metabolite of SRB and by the depolarization of cathodic areas containing high concentration of Hydrogen.

SRB growth on metal surfaces changes the properties of the electrical interface. Important changes in the type and concentration of ions, $\mathrm{pH}$ values, and oxidation-reduction potential are induced by the biofilm.

Microorganisms influence corrosion rate by changing the electrochemical conditions at the metal-solution interface. These changes may have different effects including the induction of localized corrosion [19].

Table 3. Characterization of SRB found in the four sediments.

\begin{tabular}{ccccc}
\hline Samples & Dry sediment & $\begin{array}{c}\text { Humid } \\
\text { sediment }\end{array}$ & $\begin{array}{c}\text { Surface } \\
\text { sediment }\end{array}$ & Deep sediment \\
\hline Number & $>10^{5} \mathrm{~g} / \mathrm{ml}$ & $>10^{5} \mathrm{~g} / \mathrm{ml}$ & $>10^{5} \mathrm{~g} / \mathrm{ml}$ & $>10^{5} \mathrm{~g} / \mathrm{ml}$ \\
\hline Form & Filamentous & Circular & circular & $\begin{array}{c}\text { Circular with } \\
\text { irregular edge }\end{array}$ \\
Diameter & $<1 \mathrm{~mm}$ & $<1 \mathrm{~mm}$ & $<1 \mathrm{~mm}$ & $1 \mathrm{~mm}$ \\
Color & whitish & whitish & white & white \\
Opacity & opaque & opaque & opaque & opaque \\
elevation & plate & plate & plate & plate \\
Surface & rough & rough & rough & rough \\
Consistency & strong & strong & strong & strong \\
\hline Mobility & mobile & mobile & mobile & mobile \\
\hline Morphology and & Cocci & bacillus & Coccobacillus & coccobacillus \\
Gram & $\mathrm{G}^{+}$ & $\mathrm{G}^{-}$ & $\mathrm{G}^{-}$ & $\mathrm{G}^{+}$ \\
\hline
\end{tabular}




\section{2. Methanogenic bacteria}

The results of microbiological analysis of the methanogenic bacteria are presented in tables 4 and 5. At the temperature of $37{ }^{\circ} \mathrm{C}$ and after 5 weeks of incubation, the growth of methanogenic bacteria was negligible in the four samples of deposits.

However, at an incubation temperature of $32{ }^{\circ} \mathrm{C}$, an appreciable population of the methanogenic bacteria was noticed in the four samples of deposits. Many authors have shown in their research that some methanogenic bacteria have an optimal growth between 25 and 30 ${ }^{\circ} \mathrm{C}$. Microbial methanogenesis is common in nature and is normally associated with the decomposition of organic matter [20-21]. The number of methanogenic bacteria was $10^{3}$ germs $/ \mathrm{ml}$ in the dry and humid deposit and in the deposit sample collected in the depth of filter. $10^{2}$ germs $/ \mathrm{ml}$ were found in the deposit collected from the surface of the filter. The dry and the humid deposits have a single type of methanogenic bacteria, while methanogenic bacteria isolated at the filter cartridge shown two different genres of bacteria.

The majority of bacteria were cocci and Gram positive $(83.3 \%)$ and $16.6 \%$ of bacteria were coccobacillus and Gram negative. All the methanogenic bacteria were immobile and the macroscopic characteristics differ from one type to another. The culture of methanogenic bacteria was obtained after four weeks of incubation at $32{ }^{\circ} \mathrm{C}$.

Table 4. Characterization of methanogenic bacteria at $32{ }^{\circ} \mathrm{C}$.

\begin{tabular}{ccc}
\hline Sample & Dry sediment (DS) & Humid sediment (HD) \\
\hline Counting & $10^{3} \mathrm{~g} / \mathrm{ml}$ & $10^{3} \mathrm{~g} / \mathrm{ml}$ \\
\hline Form & circular & filamentous \\
Diameter & $<1 \mathrm{~mm}$ & $>1 \mathrm{~mm}$ \\
Color & White with black center & white \\
Opacity & opaque & opaque \\
Elevation & convex & convex \\
Surface & dry & dry \\
Consistency & plate & plate \\
\hline Mobility & Immobile & Immobile \\
\hline Morphology & Cocci & Cocci \\
Gram & $\mathrm{G}^{+}$ & $\mathrm{G}^{+}$ \\
\hline
\end{tabular}

Table 4(continued). Characterization of methanogenic bacteria at $32{ }^{\circ} \mathrm{C}$.

\begin{tabular}{ccccc}
\hline Sample & \multicolumn{2}{c}{ Surface filter } & \multicolumn{2}{c}{ Deep filter } \\
\hline Counting & \multicolumn{2}{c}{$10^{3}$ germs $/ \mathrm{ml}$} & \multicolumn{2}{c}{$10^{2}$ germs $/ \mathrm{ml}$} \\
\hline Form & Circular & irregular & circular & circular \\
Diameter & $<1 \mathrm{~mm}$ & $>1 \mathrm{~mm}$ & $<1 \mathrm{~mm}$ & $>1 \mathrm{~mm}$ \\
Color & white (black center) & green & white & White(black center) \\
Opacity & opaque & opaque & opaque & translucide \\
\hline
\end{tabular}




\begin{tabular}{|c|c|c|c|c|}
\hline $\begin{array}{c}\text { Elevation } \\
\text { Surface } \\
\text { Consistency }\end{array}$ & $\begin{array}{l}\text { convex } \\
\text { dry } \\
\text { plate }\end{array}$ & $\begin{array}{l}\text { convex } \\
\text { blunted } \\
\text { plate }\end{array}$ & $\begin{array}{c}\text { convex } \\
\text { dry } \\
\text { plate }\end{array}$ & $\begin{array}{l}\text { convex } \\
\text { rough } \\
\text { viscous }\end{array}$ \\
\hline Mobility & mobile & immobile & immobile & mobile \\
\hline $\begin{array}{c}\text { Morphology } \\
\text { Gram }\end{array}$ & $\begin{array}{c}\text { Cocci } \\
\mathrm{G}^{+}\end{array}$ & $\begin{array}{c}\text { Coccobacille } \\
\mathrm{G}^{-}\end{array}$ & $\begin{array}{c}\text { Cocci } \\
\mathrm{G}^{+}\end{array}$ & $\begin{array}{c}\text { Cocci } \\
\mathrm{G}^{+}\end{array}$ \\
\hline
\end{tabular}

\section{CONCLUSIONS}

Microbiological analyses performed on deposits collected from the water injector wells, have revealed the presence of a large microbial population. These analyses also reveal a diverse nature of isolated organisms. The filter was more contaminated with bacteria than dry and wet deposits. The morphology of these bacteria is most often type Gram positive and cocci forms. The ability of bacteria to degrade organic products is a well-known phenomenon. The medium contains a mixture of SRB, MB and other cells. There metabolism products were methane gas, hydrogen sulfur, mono oxide of carbon and several other compounds. The final products associated with the intense solar radiation of summer facilitated the self ignition that lead to burn the fiberglass line.

\section{References}

[1] Vossoughi M., Shakeri M., Alemzadeh I., Chemical Engineering and Processing 42 (2003) 811-816.

[2] Euiso C., Jay R., Water Sciences Technology 23 (1991) 1259-1264.

[3] Tatyana D., Nicholas P. 2011. Fire and explosion hazards handbook of industrial chemicals. Cheremisinoff: p. 223, August $13^{\text {th }}$.

[4] Fei F., Liang D., Procedia Engineering 11 (2011) 91-99.

[5] Proce W. H., Marcia M. 2007. Edings of the International Conference on Sustainable Solid Waste Management, 5 - 7 September, Chennai, India, pp. 189-196.

[6] Shadi M., Debra R., Ruey-Hung C., Waste Management 30 (2010) 1600-1607.

[7] William H., Marcia M., Conservation and Recycling 40 (2003) 53-69.

[8] Torrenta J. G., Á. Ramírez G., Querol-Aragóna E., Grima-Olmedoa C., Medic-Pejica L., Determination of the the risk of self-ignition of coals and biomass materials. Journal of Hazardous Materials (2012) Paper in press.

[9] Tsuchiya Y., Sumi K. (1976). Spontaneous ignition: relation between ambient temperature and size of specimen. National Research Council of Canada.

[10] Franzmann, P. N., Skyring, G. W., Burton, H. R. and Deprez, P. P., Hydrobiology 165 (1985) 25-33.

[11] Chris A. P., Johannes M. S., Elijah M.T., Karl-Heinz J. R., Fuel 82 (2003) 1359-1365.

[12] Albert G., Keshab R. S., Jurg K., Zhiguo Y.,Water Research 43(2009) 2874-2884. 
[13] Katy J., Susan A., Baldwin M., Water Resources 34(3) (2000) 797-806.

[14] Ramaraj B., Bioresource Technology 55 (1996) 231-235.

[15] Friedrich W.,Applied and Environmental Microbiology 55(5) (1986) 1056-1062.

[16] Devender K. Jain, Journal of Microbiological Methods 22 (1995) 27-38.

[17] Zhang C., Wena F., Cao Y., Procedia Environmental Sciences 10 (2011) 1177-1182.

[18] Sherar B.W.A., Power I.M., Keech P.G., Mitlin S., Southam G., Shoesmith D.W. Corrosion Science 53 (2011) 955-960.

[19] Héctor A. Videla, Liz K. Herrera, International Microbiology 8 (2005) 169-180.

[20] Martina M., Peter F., Applied and Environmental Microbiology (2005) 8191-8200.

[21] Zaikus J. G., Winfrey M. R., Applied and Environmental Microbiology 31(1) (1976) 99-107. 